\title{
LEVELS OF POLYCYCLIC AROMATIC HYDROCARBONS (PAHS) IN FISH SAMPLES FROM DIFFERENT PROCESSING METHODS
}

\author{
A.U. Itodo ${ }^{1 *}$, V.O. Nnodim ${ }^{1,2}$. S. Ande ${ }^{1}$, H.U. Itodo ${ }^{1}$ and O. Ofoegbu ${ }^{3}$ \\ ${ }^{1}$ Department of Chemistry and Centre for Agrochemical Technology \& Environmental Research \\ (CATER), Federal University of Agriculture, PMB 2373 Makurdi, Nigeria. \\ ${ }^{2}$ Department of Food Safety and Applied Nutrition, National Agency for Food and Drug \\ Administration and Control, Lafia, Nigeria \\ ${ }^{3}$ Polymer, Nano materials and Molecular Recognition Research Group, Department of Chemistry, \\ College of Science, Federal University of Agriculture Makurdi, Benue State Nigeria \\ *Corresponding author: itodoson2002@gmail.com, +2348039503463 \\ Received 23 December 2019; accepted 05 September 2020, published online 10 October 2020
}

\begin{abstract}
Fish is easily contaminated from water prone to water pollution. In this study, the levels of polycyclic aromatic hydrocarbons (PAHs) in fish samples processed, using three methods and marketed in Makurdi, Benue state, were determined. The samples were coded as SF (Smoked Fish), SD (Sundried) and FD (fried) fish samples. PAHs in the samples were quantified, using gas chromatography - mass spectrometer (GC-MS). The $\Sigma_{16} \mathrm{PAH}$ concentrations were in the range of 0.2$10.0 \mathrm{mg} / \mathrm{kg}$. Both LPAHs/HPAHs and the binary diagnostic ratios of PAHs indicated pyrogenic and petrogenic sources $\Sigma_{16} \mathrm{PAH}$ and their dominant PAH ring-types were separately computed for each sample. The six-membered ring PAHs in smoked fish was $32.07 \%$ (with Bezo(ghi)perylene as most dominant). High levels of six member ring PAHs (Dibenz(a,h) anthracene) were also found in Sundried fish and fried fish contain Dibenz $(\mathrm{a}, \mathrm{h})$ anthracene. Generally, the PAHs concentrations in the samples, pointed more at pyrogenic than the petrogenic source. With exception of the five and six membered rings, estimated PAH levels were within the NAFDAC permissible limits.
\end{abstract}

Keywords: PAHs, Fish, Pollutants, Petrogenic, Pyrogenic, Diagnostic ratio

\section{Introduction}

Harvested fish requires preservation and storage to increase the shelf life. Major methods of fish processing and preservation have been reported $[1,2,3]$. The traditional methods of processing are often inefficient and unhygienic due to contamination [4]. The presence of PAHs in food is usually a consequence of the nature of these compounds in the environment at their formation during cooking processes or as a result of the manufacturing processes [5]. Despite being environmental contaminants, PAHs are formed in food processing, such as drying, grilling, roasting, and smoking. PAHs tend to accumulate in water sediments over time [6].

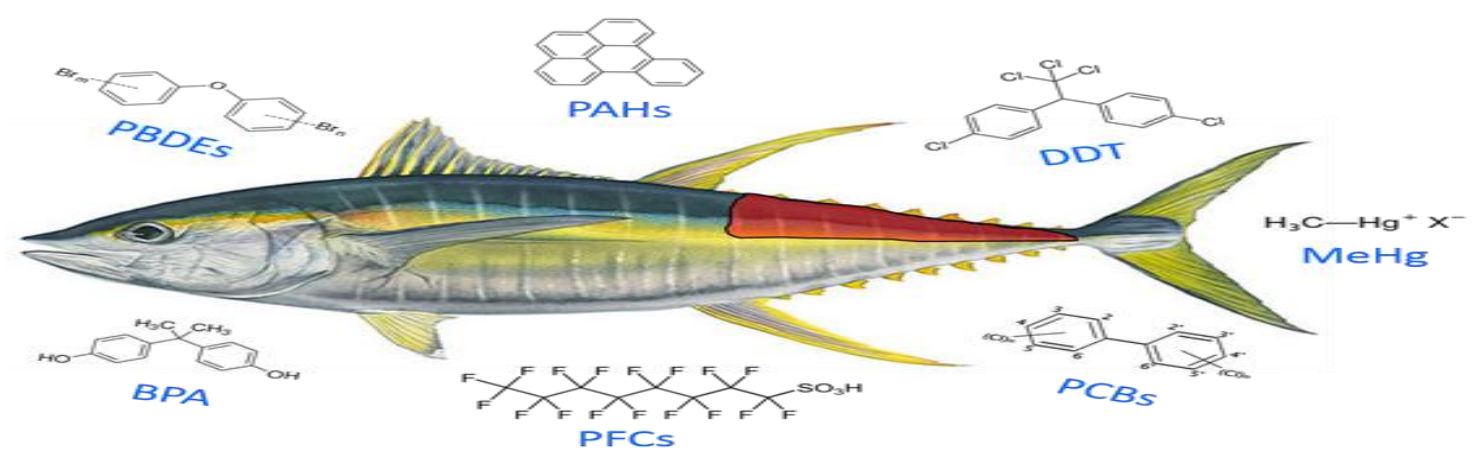

Figure 1: Chemical Structures of Some Persistent Organic Pollutants (POPs) and Methyl Mercury Frequently Detected in the Dorsal Muscle Tissue (red) of Fish 7].

The origin of PAHs in the environments include pyrogenic, petrogenic, and biological sources [8]. Low molecular weight PAHs
(LPAHs) include two to three member rings while the high molecular weight PAHs (HPAHs) contain four to six rings and are 
highly carcinogenic. PAH diagnosis, with LPAHs/HPAHs $>1$ indicates petrogenic while more than one indicates pyrogenic origin. Several authors used the ratios of individual PAHs levels for source identification $[9,18,20]$.

Table 1 is the priority PAHs list. The 16 PAHs are divided into five groups according to the number of the aromatic rings; 2- rings, 3-rings, 4-rings, 5-rings and 6-rings PAHs [10].

The rising incidence of health issues in which experts have implicated fish consumption as one of the entrant route for the toxicants, creates the need to evaluate the presence and impacts of contaminants in fish, particularly the organic types. This study explores the level of PAHs in fish samples that are processed and sold in Makurdi, Benue state, Nigeria. The limitation on "PAHs contributory role by the fish species used in this study and possibly, their habitat" is awknowledged. However, the study is an expository study of the fish samples processed in Markurdi, with their common and respective processing methods.

\section{Materials and Methods}

All reagents were of analytical grade. Dichloromethane (DCM >99 \%), HPLC grade acetone and HPLC grade methanol and Commercial PAH standard containing 16 USEPA priority PAHs were supplied by Bristol Chemicals for Sigma Aldrich. The determination of PAHs in the sampled fish was carried out using the ultrasonication extraction followed by Gas ChromatographyMass Spectrophotometer (GC-MS) with Agilent Technologies GC-MS made in Germany.

\section{Table 1: The 16 USEPA Priority PAHs}

\begin{tabular}{lll}
\hline PAHs compounds & $\begin{array}{l}\text { Molecular } \\
\text { Formula }\end{array}$ & $\begin{array}{l}\text { Carcinogenic } \\
\text { activity }\end{array}$ \\
\hline Naphthalene & $\mathrm{C}_{10} \mathrm{H}_{8}$ & + \\
Phenanthrene & $\mathrm{C}_{14} \mathrm{H}_{10}$ & - \\
Anthracene & $\mathrm{C}_{14} \mathrm{H}_{10}$ & \pm \\
Fluoranthene & $\mathrm{C}_{16} \mathrm{H}_{10}$ & - \\
Pyrene & $\mathrm{C}_{16} \mathrm{H}_{10}$ & - \\
Chrysene & $\mathrm{C}_{18} \mathrm{H}_{12}$ & - \\
Benzo(a)anthracene & $\mathrm{C}_{18} \mathrm{H}_{12}$ & \pm \\
Benzo(b)fluoranthene & $\mathrm{C}_{18} \mathrm{H}_{12}$ & ++ \\
Benzo(k)fluoranthene & $\mathrm{C}_{20} \mathrm{H}_{12}$ & + \\
Benzo(e)pyrene & $\mathrm{C}_{20} \mathrm{H}_{12}$ & \pm \\
Benzo(a)pyrene & $\mathrm{C}_{20} \mathrm{H}_{12}$ & +++ \\
Perylene & $\mathrm{C}_{20} \mathrm{H}_{12}$ & \pm \\
Benzo(ghi)perylene & $\mathrm{C}_{20} \mathrm{H}_{12}$ & \pm \\
Dibenzo(ah)anthracenes & $\mathrm{C}_{22} \mathrm{H}_{14}$ & +++ \\
Indeno(cd)pyrene & $\mathrm{C}_{22} \mathrm{H}_{12}$ & + \\
Coronene & $\mathrm{C}_{24} \mathrm{H}_{12}$ & \pm \\
\hline (+++) - carcinogenic to experimental animals; \pm - data are \\
inadequate to permit an evaluation of the carcinogenicity of \\
substance to experimental animals. - no evidence that substance \\
is carcinogenic to experimental animals [10].
\end{tabular}

Table 1 shows some common PAHs, their molecular formalar and carcinogenic activity

Sampling: As presented in Table 2, (i) smoked (ii) Fried and (iii) sundried fish were randomly selected from dealers in Wurukum and Northbank markets, Makurdi. Samples were packaged in perforated polythene bags and were refrigerated at $4^{\circ} \mathrm{C}$ before analysis [11].

\section{Table 2: Sample description and Codes}

\begin{tabular}{llll}
\hline S/N & Fish species & Processing Method & Sample Code \\
\hline 1 & Tilapia zilli & Smoking & SF \\
2 & Ethmalosa fimbriata & Sun-drying & SD \\
3 & Micropogon undulatus & Frying & FD \\
\hline
\end{tabular}

\section{Extraction and clean-up experiment}

A documented sample pre-treatment method [12] was adopted. The ground samples (10 g) was weighed into conical flask. $20 \mathrm{~mL}$ of the mixture of analytical grade Dichloromethane (DCM) and Acetone was added to the samples $(1: 1 \mathrm{v} / \mathrm{v})$. The samples were sonicated for 45 min. The clear portion was decanted into another beaker. The extraction procedure was repeated by adding $20 \mathrm{~mL}$ of the mixture of DCM and acetone and then allowed to undergo ultrasonication. The extract was combined and later cleaned up [13,14]. For the clean-up experiment, an SPE column was packed with cotton wool containing anhydrous sodium sulphate and silica gel. Method TG51991 was carefully followed. Briefly, the parked SPE cartridge was conditioned with 3 $\mathrm{mL}$ hexane. The sample extract was applied to the cartridge and eluted with $5 \mathrm{~mL}$ hexane into an evaporator glass tube. The solvent was evaporated to near dryness at $40{ }^{\circ} \mathrm{C}$, using a 
blow-down apparatus under gentle stream of nitrogen. Sample was reconstituted in $180 \mu \mathrm{L}$ of cyclohexane with $20 \mu \mathrm{L}$ of injection standard [15].

GC/MS operating condition: An Agilent Technologies GC-MS comprises of 7890A gas chromatography and MS 5975C mass spectrometer detector was used in this study. The instrument comprises a column thickness of $0.25 \mu \mathrm{m}$, internal diameter of $0.32 \mathrm{~mm}$ and Helium as carrier gas at the rate of $1 \mathrm{~mL} / \mathrm{min}$. The column temperature was initially held at $70{ }^{\circ} \mathrm{C}$ for 3 mins, increased to $160{ }^{\circ} \mathrm{C}$ at a rate of $20{ }^{\circ} \mathrm{C} / \mathrm{min}$, then to $210{ }^{\circ} \mathrm{C}$ at a rate of 3 ${ }^{\circ} \mathrm{C} / \mathrm{min}$ and to a final temperature of $310^{\circ} \mathrm{C}$ at a rate of $5{ }^{\circ} \mathrm{C} / \mathrm{min}$ and held for $10 \mathrm{mins}$ and transfer line of $320^{\circ} \mathrm{C}$. The mass spectrometer (MS) condition was electron impact positive ion mode. The PAHs identification was based on retention time $[13,14]$.

Analytical Quality Controls

To assure recovery efficiency, triplicate analyses were conducted on PAH standard reference materials provided by national institute of standards and technology (NIST). Recovery studies showed that the efficiency is greater than $90 \%$, with a coefficient of variation $(\mathrm{CV})$ of $6-10 \%$ for all 16 PAHs. The quality assurance was also monitored by analyzing blanks sample spiked with known quantity of each PAHs standard. The values of PAHs in the blanks samples were below the detection of the instrument $(0.01 \mu \mathrm{g} / \mathrm{mL})$.

\section{Results and Discussion PAHs Concentrations in Samples:}

Figs. 2 is a typical chromatograms obtained in this study. Tables 3-5 showed the result of PAHs concentration in fish samples. The result of Diagnostic ratio is presented (Table 6)

PAHs in smoked fish: From Table 3, the two member rings PAHs detected were Naphthalene, Naphthalene, 2 methyl, 00009012-0 Napthalene, Biphenylene, and Acenaphthene with $0.0029 \mathrm{mg} / \mathrm{kg}, 0.0057$ $\mathrm{mg} / \mathrm{kg}, 0.0063 \mathrm{mg} / \mathrm{kg}, 0.00124 \mathrm{mg} / \mathrm{kg}$, and $0.0222 \mathrm{mg} / \mathrm{kg}$ respectively. The elevation of Biphenylene could be as a result of incomplete combustion of materials used during smoking process [16]. Three-member ring PAHs compound detected have the following concentration; $0.0018 \mathrm{mg} / \mathrm{kg}$ and 0.0026 $\mathrm{mg} / \mathrm{kg}$ for fluorine and Phenathrene respectively. The four member rings estimated have the following concentration; 0.0021 $\mathrm{mg} / \mathrm{kg}, 0.0021 \mathrm{mg} / \mathrm{kg}$ and $0.0015 \mathrm{mg} / \mathrm{kg}$ for fluoranthene, pyrene and Tryphyenylene respectively. The five member rings (Benz (a)anthracene, Benzo(b) Fluoranthene, and Benzo(a)pyrene) has concentrations of 0.0012 $\mathrm{mg} / \mathrm{kg}, \quad 0.0018 \mathrm{mg} / \mathrm{kg}$ and $0.0025 \mathrm{mg} / \mathrm{kg}$ respectively while the six member rings including Indeno(1,2,3-cd) Pyrene, $\operatorname{Dibenz}(\mathrm{a}, \mathrm{h})$ anthracene and Benzo(ghi) perylene were available at $0.0051 \mathrm{mg} / \mathrm{kg}$, $0.0076 \mathrm{mg} / \mathrm{kg}$, and $0.0127 \mathrm{mg} / \mathrm{kg}$ concentrations. The total concentration of PAHs components and their respective percentage abundance were recorded according to their member rings; 2 rings $(0.0385 \mathrm{mg} / \mathrm{kg}$ and $9.673 \%), 3$ rings $(0.9044$ $\mathrm{mg} / \mathrm{kg}$ and $9.673 \%), 4$ rings $(0.0057 \mathrm{mg} / \mathrm{kg}$ and $7.199 \%), 5 \mathrm{ring}(0.0054 \mathrm{mg} / \mathrm{kg}$ and 6.889 $\%)$ and 6 rings $(0.050 \mathrm{mg} / \mathrm{kg}$ and $32.07 \%)$ respectively. The level of PAHs in smoked fish sample depends on the heat source, temperature, flame intensity, flame combustion. [17]. 


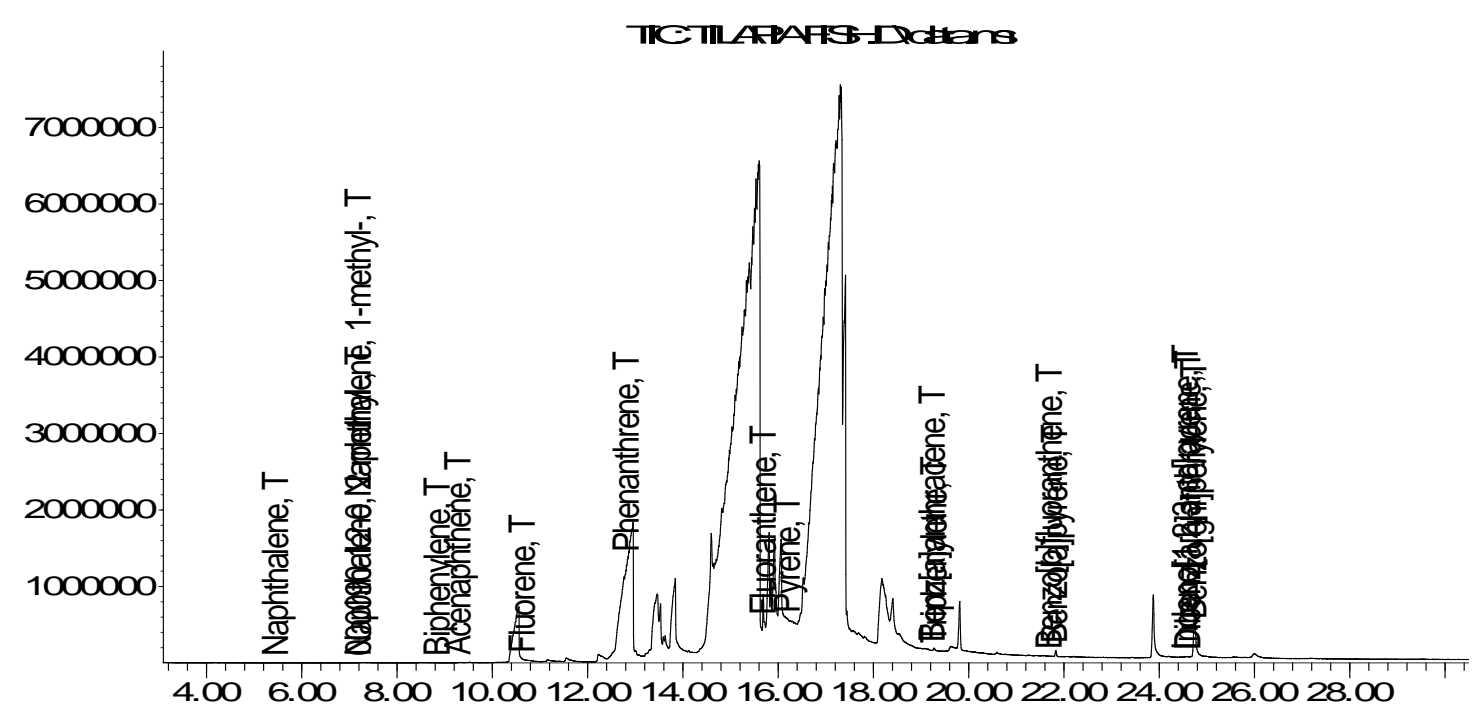

Time->

Figure 2: Chromatogram of PAHs in Smoked Fish sample

Table 3: PAH Concentrations (mg/kg) in Smoked Fish Sample

\begin{tabular}{|c|c|c|c|c|c|c|c|}
\hline $\mathrm{S} / \mathrm{N}$ & PAH & Abbrev. & $\begin{array}{l}\text { Conc. } \\
\mathrm{mg} / \mathrm{kg}\end{array}$ & in & $\begin{array}{l}\text { Abundance } \\
\%\end{array}$ & rings & $\Sigma_{16} \mathrm{PAH}$ in $\mathrm{mg} / \mathrm{kg} /(\%)$ \\
\hline & Two Member Ring PAHs & & & & & & \\
\hline 1 & Naphthalene & NAP & 0.0029 & & 3.674 & 2 & \\
\hline 2 & Naphthalene, 2 methyl- & $2 \mathrm{MNPH}$ & 0.0057 & & 7.214 & 2 & \\
\hline 3 & 000090-12-0 Napthalene & $12 \mathrm{NAP}$ & 0.0063 & & 7.964 & 2 & \\
\hline 4 & Biphenylene & $\mathrm{BP}$ & 0.0012 & & 1.566 & 2 & \\
\hline \multirow[t]{2}{*}{5} & Acenaphthene & $\mathrm{ACE}$ & 0.0221 & & 27.945 & 2 & $0.0383(9.673)$ \\
\hline & Three Member Ring PAHs & & & & & & \\
\hline 6 & Fluorene & FLR & 0.0018 & & 2.234 & 3 & \\
\hline 7 & Phenanthrene & PHE & 0.0026 & & 3.250 & 3 & $0.9044(3.250)$ \\
\hline \multicolumn{8}{|c|}{ Four Member Ring PAHs } \\
\hline 8 & Fluorathene & FLT & 0.0021 & & 2.689 & 4 & \\
\hline 9 & Pyrene & PYR & 0.0021 & & 2.603 & 4 & \\
\hline \multirow[t]{2}{*}{10} & Triphyenylene & TRP & 0.0015 & & 1.907 & 4 & $0.0057(7.199)$ \\
\hline & Five Member Ring PAHs & & & & & & \\
\hline 11 & Benz (a)anthracene & $\mathrm{BaA}$ & 0.0012 & & 1.495 & 5 & \\
\hline 12 & Benzo(b)Fluoranthene & $\mathrm{B}(\mathrm{b}) \mathrm{FA}$ & 0.0018 & & 2.208 & 5 & \\
\hline \multirow[t]{2}{*}{13} & Benzo(a)pyrene & $\mathrm{B}(\mathrm{a}) \mathrm{P}$ & 0.0025 & & 3.186 & 5 & $0.0054(6.889)$ \\
\hline & Six Member Ring PAHs & & & & & & \\
\hline 14 & Indeno(1,2,3-cd)Pyrene & IP & 0.0051 & & 6.399 & 6 & \\
\hline 15 & Dibenz(a,h) anthracene & $\mathrm{D}(\mathrm{a}, \mathrm{h}) \mathrm{A}$ & 0.0076 & & 9.630 & 6 & \\
\hline \multirow[t]{2}{*}{16} & Bezo(ghi) perylene & $\mathrm{B}$ (ghi)P & 0.0127 & & 16.041 & 6 & $0.0509(32.07)$ \\
\hline & tPAHs & & 0.0793 & & & & $0.0793(59.081)$ \\
\hline
\end{tabular}


Table 4: PAH Concentrations (mg/kg ) in Sundried Fish Sample

\begin{tabular}{|c|c|c|c|c|c|c|}
\hline $\mathrm{S} / \mathrm{N}$ & PAH & Abbre. & Conc.(mg/kg) & $\begin{array}{l}\text { Abundan } \\
\text { ce } \%\end{array}$ & $\begin{array}{l}\text { Number } \\
\text { of rings }\end{array}$ & $\begin{array}{l}\Sigma_{16} \mathrm{PAH} ; \quad \mathrm{mg} / \mathrm{kg} \\
/(\%)\end{array}$ \\
\hline & \multicolumn{6}{|c|}{ Two Member Ring PAHs } \\
\hline 1 & Naphthalene & NAP & 0.0022 & 4.296 & 2 & \\
\hline 2 & $\begin{array}{l}\text { Naphthalene, } 2 \\
\text { methyl- }\end{array}$ & 2MNAP & - & - & 2 & \\
\hline 3 & $\begin{array}{l}\text { 000090-12-0 } \\
\text { Napthalene }\end{array}$ & 12NAP & - & - & 2 & \\
\hline 4 & Biphenylene & $\mathrm{BP}$ & - & - & 2 & \\
\hline \multirow[t]{2}{*}{5} & Acenaphthene & Ace & 0.001964 & 3.929 & 2 & $0.0041(8.225)$ \\
\hline & \multicolumn{6}{|c|}{ Three Member Ring PAHs } \\
\hline 6 & Fluorene & FLR & 0.0018 & 3.663 & 3 & \\
\hline \multirow[t]{2}{*}{7} & Phenanthrene & Phen & 0.0023 & 4.584 & 3 & $0.0041(8.247)$ \\
\hline & \multicolumn{6}{|c|}{ Four Member Ring PAHs } \\
\hline 8 & Fluorathene & FLT & 0.0020 & 4.087 & 4 & \\
\hline 9 & Pyrene & Pyr & 0.0013 & 2.523 & 4 & \\
\hline \multirow[t]{2}{*}{10} & Triphyenylene & $\operatorname{Trp}$ & 0.0012 & 2.347 & 4 & $0.0045(8.957)$ \\
\hline & \multicolumn{6}{|c|}{ Five Member Ring PAHs } \\
\hline 11 & Benzo (a)anthracene & $\mathrm{B}(\mathrm{a}) \mathrm{A}$ & 0.0015 & 3.073 & 5 & \\
\hline 12 & Benzo(b)Fluoranthene & $\mathrm{B}(\mathrm{a}) \mathrm{F}$ & 0.0021 & 4.153 & 5 & \\
\hline 13 & Benzo(a)pyrene & $\mathrm{B}(\mathrm{a}) \mathrm{P}$ & 0.0015 & 3.021 & 5 & $0.0051(10.247)$ \\
\hline & \multicolumn{6}{|c|}{ Six Member Ring PAHs } \\
\hline 14 & $\begin{array}{l}\text { Indeno(1,2,3- } \\
\text { cd)Pyrene }\end{array}$ & IP & 0.0075 & 14.951 & 6 & \\
\hline 15 & $\begin{array}{l}\operatorname{Dibenz}(\mathrm{a}, \mathrm{h}) \\
\text { anthracene }\end{array}$ & $\mathrm{DB}(\mathrm{ah}) \mathrm{A}$ & 0.0191 & 38.191 & 6 & \\
\hline 16 & $\begin{array}{l}\text { Bezo(ghi) perylene } \\
\text { tPAHs }\end{array}$ & $\mathrm{B}$ (ghi)P & $\begin{array}{l}0.0056 \\
0.0500\end{array}$ & 11.182 & 6 & $\begin{array}{l}0.0322(64.324) \\
0.05(100)\end{array}$ \\
\hline
\end{tabular}

PAHs in sundried fish: The results in Table 4 showed that the two-member ring detected were Naphthalene $(0.0022 \mathrm{mg} / \mathrm{kg})$ and Acenaphthene $(0.0019 \mathrm{mg} / \mathrm{kg})$ with the percentage abundance of $8.225 \%$. The total concentration $(0.0041 \mathrm{mg} / \mathrm{kg})$ for the two member rings are within the permissible limit $(0.002 \mathrm{mg} / \mathrm{kg}$ and $0.005 \mathrm{mg} / \mathrm{kg}$ respectively). The presence of naphthalene in sundried fish could be due to the route of exposure such as air. These confirmed that lower molecular weights PAHs are air bone and certain PAHs are present in both particulate and gaseous phase depending on their votality. The three member rings detected are fluorene $(0.0018$ $\mathrm{mg} / \mathrm{kg})$ and Phenanthrene $(0.0023 \mathrm{mg} / \mathrm{kg})$ with a total concentration of $0.00412 \mathrm{mg} / \mathrm{kg}$ and percentage abundance of $8.24 \%$. The lower molecular weight PAHs compounds presence are naphthalene, acenaphthalene, fluorine and phenanthalene and this could be as a result of lower or moderate temperature involved during drying. The four member rings detected are Fluoranthrene $(0.0020 \mathrm{mg} / \mathrm{kg})$, Pyrene $(0.0013 \mathrm{mg} / \mathrm{kg})$ and Triphenylene $(0.0012$ $\mathrm{mg} / \mathrm{kg}$ ). The total concentration of four member rings and the percentage abundance were $0.0048 \mathrm{mg} / \mathrm{kg}$ and $8.957 \%$. All the five member rings were detected with the concentration of $0.0015 \mathrm{mg} / \mathrm{kg}, 0.0021 \mathrm{mg} / \mathrm{kg}$ and $0.0015 \mathrm{mg} / \mathrm{kg}$ for Benz(a)anthracene, Benzo(b)fluoranthene and Benzo(a)pyrene respectively. The five membered rings have a total concentration of $0.0051 \mathrm{mg} / \mathrm{kg}$ and $10.247 \%$ (percentage abundance). The results obtained showed that the six-member ring 
were detected with the concentration of 0.0075 $\mathrm{mg} / \mathrm{kg}, 0.0191 \mathrm{mg} / \mathrm{kg}$, and $0.0056 \mathrm{mg} / \mathrm{kg}$ for Benzo (1,2,3), pyrene and Benzo (ghi) perphrene respectively. Total PAHs components detected were $0.0321 \mathrm{mg} / \mathrm{kg}$ for concentration and percentage abundance of $64.324 \%$. Among the six member rings, the Diazo(a) anthracene $(0.2 \mathrm{mg} / \mathrm{kg})$ has the highest PAHs component compared to that of smoke dried samples $(0.008 \mathrm{mg} / \mathrm{kg})$. The total concentration of PAHs components in sundried fish sample $(0.0499 \mathrm{mg} / \mathrm{kg})$ were higher than the permissible limit in fish as recommend by EU $(0.002 \mathrm{mg} / \mathrm{kg})$. These result agrees with similar report [18]. This is an indication that high concentration of PAHs component could be due the level of organic matter present in the environment.

PAHs compounds in fried fish: Table 5, showed the PAHs concentrations in fried fish samples. The study showed that only Biphenylene $(0.0021 \quad \mathrm{mg} / \mathrm{kg}) \quad$ and Acenaphthalene $(0.0015 \mathrm{mg} / \mathrm{kg})$ were detected in two members aromatic PAHs rings. They are within the acceptable limit as recommended by WHO and EU $(0.002 \mathrm{mg} / \mathrm{kg}$ and $0.005 \mathrm{mg} / \mathrm{kg}$ ). The total concentration and percentage abundance for the two member rings are $0.0036 \mathrm{mg} / \mathrm{kg}$ and $8.382 \%$. Phenanthrene was the only three member rings detected with the concentration of 0.0012 $\mathrm{mg} / \mathrm{kg}$ with percentage abundance of $2.80463 \%$. The lower concentration of phenanthrene observed in oil fried fish sample could be due to diffusion of phenanthrene from fish fraction which could reduce the level in fish during frying [11]. The four member rings and five member rings were not detected. The six member rings. PAHs concentration detected were Indeno $(1,2,3)$ pyrene $(0.0058$ $\mathrm{mg} / \mathrm{kg})$ Dibenz $(\mathrm{a}, \mathrm{h})$ anthracene $(0.0274 \mathrm{mg} / \mathrm{kg}$ ,) and Benzo(ghi) perylene $(0.0050 \mathrm{mg} / \mathrm{kg})$ respectively. The result showed that Dibenz(a,h)anthracene are higher than the permissible limit $(0.002 \mathrm{mg} / \mathrm{kg}$ and 0.005 $\mathrm{mg} / \mathrm{kg}$ ). The total concentration and percentage abundance of six-member ring was recorded to be $0.03822 \mathrm{mg} / \mathrm{kg}$ and $88.814 \%$. In this study, $\sum_{16} \mathrm{PAHs}$ compounds in fried fish sample was recorded $0.0430 \mathrm{mg} / \mathrm{kg}$.

\section{PAHs sources based on diagnostic ratio}

The PAHs formation can either be natural or anthropogenic [19]. Pyrogenic sources are those including combustion of hydrocarbons or indeed any organic materials (engines exhaust, fire, and aluminium smelting resulting in atmospheric deposition and waste water effluents) while Petro-genic sources originated from oil, petroleum, related activities as well as natural sources. Pyrolytic mixture of PAHs enters the aquatic environments through the deposition of atmospheric emission directly into the water or soil followed by soil erosion. PAHs are found in the ambient air in gas-phase and as sorbet to aerosols [20,21]. The PAHs components from two to three member rings and some alkyl substitution points at petrogenic contaminants whereas four to six rings PAHs are more toxic and thermodynamically stable than those from petrogenic source. They were identified with pyrogenic origin. The molecular weight ratios are mostly used to differentiate PAHs from Pyrogenic and petrogenic origins [21]. The result obtained in this study showed the ratio of $\sum \mathrm{LPAH} / \mathrm{HPAH}$ in sundried, smoked fish and fried fish sample are less than 1 , which indicated that the source or origin is pyrogenic. This showed that the source of most these fish samples could be derived from the incomplete combustion of organic matter and fossil fuels from wood and fuel respectively. The ratio of (IPy/IPy+Bghi) $>0.5$ gives a pyrogenic origin in all the processed samples, but the reverse is the case in smoke fish sample with IPY/IPY + Bghi $<0.5$ which indicated petrogenic origin. $\mathrm{BaA}(\mathrm{BaA}+\mathrm{Try})$ ratio $>0.350$ indicated pyrogenic while $<0.2$ is attributed to petrogenic source. The study therefore revealed that most of the sample's source was pyrogenic which could be as a result of antropogenic activities and organic waste present in the environment of origin.

Statistical test of significance $(\mathrm{p}<0.05)$ indicated that the differences in PAH levels between the processed fish samples were not significant. With exception of the six member rings, PAH levels investigated in this study are within threshold limits suggested by existing legislations. 
Table 5: PAH Concentrations (mg/kg) in Fried Fish Sample

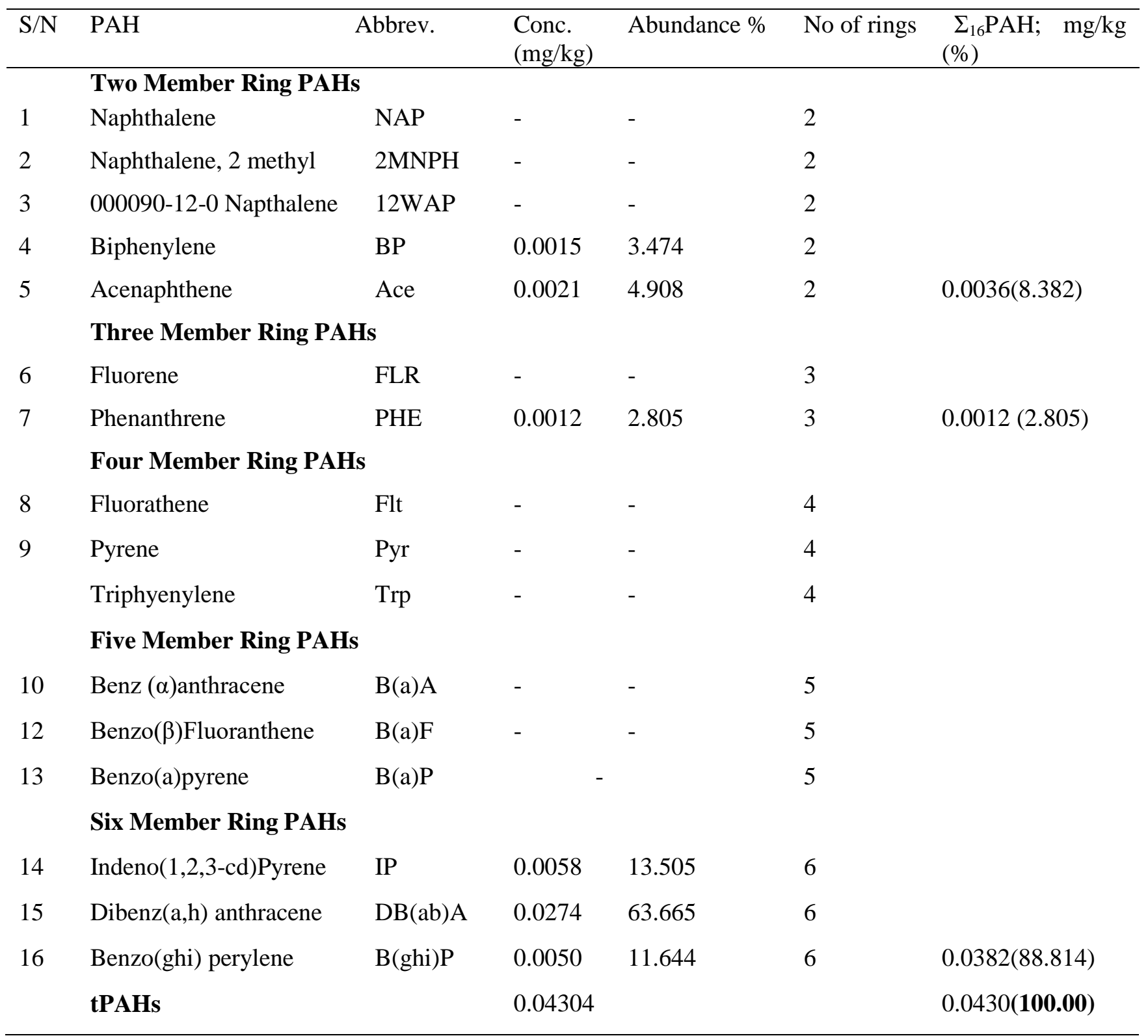

Table 6: Source of PAHs based on Characteristic Diagnostic Ratios

\begin{tabular}{llllll}
\hline PAHs Ratio & value & Origin (source) & SM & FD & SD \\
\hline PHen/ANth & $<10$ & Pyrogenic & NA & NA & NA \\
PHen/ANth & $>10$ & pyrogenic & NA & NA & NA \\
Pyr $<$ Flth & - & Pyrogenic & Pyrogen & pyrogenic & pyrogenic \\
FLth $>$ PYr & - & Pyrogenic & Pyrogenic & pyrogenic & pyrogenic \\
PYR/FLth & $>1$ & Petrogenic & Pyrogenic & pyrogenic & pyrogenic \\
IPy/(Ipy + Bghi) & $>0.5$ & pyrogenic & petrogenic & pyrogenic & pyrogenic \\
IPy/(IPy +Bghi) & $<0.2$ & Petrogenic & Pyrogenic & pyrogenic & pyrogenic
\end{tabular}


$\Sigma \mathrm{LPAH} / \Sigma \mathrm{HPAH} \quad<1 \quad$ Pyrogenic Pyrogenic pyrogenic pyrogenic

NA-Not Applicable.

\section{Conclusion}

PAHs levels in fish samples, processed using different methods were investigated. Results from this studies revealed that the high molecular weight PAHs, majorly the six membered rings were present than the lower member ring PAHs. Generally, PAHs in fish samples underscores the method of preservation since the differences in the PAH values reported were non-significant. Overall, estimated PAHs levels in the fishes, processed using different methods were within acceptable concentrations prescribed by existing legislation. Exceptions to this generalization were the levels of five member ring (Benzo(a)pyrene) and six member ring (Dibenzo(ah)anthracenes) PAHs, known for high carcinogenicity.

\section{REFERENCES}

1. B.U. Ibrahim (2017), Assessment of the nutritional quality of smoked catfish (Clarias gariepinus) in lapai, Niger state, Nigeria. Science world Journal, $12(1), 1-21$.

2. K.A. Abbas, A. Mohamed, B. Jamilah, M. Ebrahimian (2008), A review on correlation between fish freshness and $\mathrm{pH}$ during cold storage. American Journal of Biochemistry and Biotechnology $y_{2}$ 4(4),416-421.

3. E.A. Adesulu (2007), The fresh water fishes and fisheries of Nigeria. Macmillan Publishers Lagos, Nigeria, P.397.

4. D. Barcelo, M. Farre (2012), Emerging Organic contaminants and Nanomaterials in food. $H D B_{2}$ Jounal of Environmental Chemistry, 20,1-6.

5. N.E. Awad, A.M. Ibrahim, S.M. Mohamed, H.R. (2018), Levels of Polycyclic Aromatic Hydrocarbons in Fried Tilapia Fish (O. niloticus) using GC-MS, Journal of Food Sci Nutr Res.. 1(1), 10-17.
6. C. Xavier, C. Jerome (2014), Pathology and fish exposure monitoring and adverse effects from molecular to individual level. Environmental Science and Pollution Research, 21 (24),13685 13688.

7. S. C. T. Nicklisch, D.R. Steven, P.M. Aaron, G. Tufan, T.B. Lindsay, M.V. Lydia, C. Cristina, L. Greg, S. Stuart, C. Geoffrey, H. Amro (2016), Global marine pollutants inhibit $\mathrm{P}$ glycoprotein: Environmental levels, inhibitory effects, and cocrystal structure. Science Advances, 2 (4), 112, e1600001.

8. IARC (2010), International Agency for Research on cancer Some nonheterocyclic PAHs and some related exposures. on the monographs evaluation of carcinogenic risks to humans, 92,765-771.

9. M. A. Younis1, Y.A. Soliman, E.M. Elkady and M.H. El-Naggar (2018), Assessment of polycyclic aromatic hydrocarbons in surface sediments and some fish species from the Gulf of Suez, Egypt, Egyptian Journal of Aquatic Biology \& Fisheries, 22(4), 49-59.

10. J. Haihua, Q.Wang, N. Zhao, B. Jin, X. Zhuang, Z. Bai (2017), Distributions and Sources of PAHs in Soils around a Chemical Plant in Shanxi, China.. International Journal of Environmental Research and Public Health $144_{2} 1198$.

11. B. Muyela, A. Shitandi, R. Ngure (2012), Determination of Benzopyrene levels in smoked and oil fried late niloticus, International Food Research Journals 19 (4) 1 1595-1600.

12. J.H. Christensen, A. Hojgard, L. Duedahl- Olesena, K. Granbya, M. Timm- Heinrich (2010), Influence of Smoking parameters on the 
concentration of PAHs in Danish Smoke fish. Food Additives and contaminants; Part A, 27 (9),12941305 .

13. M.I. Arowojolu, S.M. Tongu, A.U. Itodo, S.T. Yinusa, K.A. Basheeru, S. Mejida (2018), Determination of PAHs in Water and Sediment of River Benue in Makurdi Metropolis, Nigeria. Chemical Science International Journal, (2),1-10.

14. N.E. Díaz-Moroles, H.J. Garza-Ulloa, R. Castro-Ríos, E.G. Ramírez-Villarreal, J.M. Barbarín-Castillo, S.M. DelaLuz, T.N. Waksman-de (2007), A comparison of the performance of two chromatographic and three extraction techniques for the analysis of PAHs in sources of drinking water, Journal of chromatographic science 45(2) 57-62.

15. K. Mittendorf, L. Hollosi, E. Ates, K. Bousova, (2010), Determination of Polycyclic romaticHydrocarbons (PAHs) and AliphaticHydrocarbons in Fish by GC-MS/MS. Thermo Fisher Scientific, Method, 5199, 1-8.

16. C.O. Ujowundu, K.L. Ihekweazu, C.S Alisi, F.N. Ujowundu and C.U. Igwe (2014), Procarcinogens: PAHs and Heavy Metal Content in Some Locally Processed Foods in South Eastern Nigeria, British Journal of Applied Science \& Technology $y_{2}$ 4(1), 249-260.

17. S.T. Ubwa, J. Abah, L. Tarzaa, R. L. Tyohemba \& U. J. Ahile (2015), Effects of Traditional Smoking Methods on the Concentrations of Polynuclear Aromatic Hydrocarbons (PAHs) in Some Species of Smoked Fish Traded in Benue State, Nigeria, Journal of Food Research, 4 (2), 119125.

18. I. Tongo, E.E. Etor, L.I.N. Ezemonye (2018), Human Health Risk Assessment of PAHs in Fish and Shell fish from Amariaria Community, Bonny River, Nigeria. Applied Science and Environmental Management, 22 (5) ${ }_{2} 731-736$..

19. J.N. Edokpayi, J.O. Odiyo, E.P. Oluwaseun, T.A.M. Msagati (2016),
Determination and Distribution of PAHs in Rivers, Sediments and Wastewater Effluents in Vhembe District, South Africa. International Journal of Environmental Research and Public Health, 13(4), 387.

20. A.U. Itodo, T.T. Akeju, H.U. Itodo (2019), PAHs in Crude Oil Contaminated Water from Ese-Odo Offshore, Nigeria, Annals of Ecology and Environmental Science, 3 (1),1219.

21. I.A. Hussein, M.S.M. Mansour (2015) ${ }_{2}$ A review on PAHs: Source, environmental impact, effect on human health and remediation, Egyptian Journal of Petroleum, $\mathbf{2 5}, 107-123$. 